\title{
Antioxidant activity of twenty five plants from Colombian biodiversity
}

\section{Oscar M Mosquera/ ${ }^{+}$, Yaned M Correa, Diana C Buitrago, Jaime Niño}

\author{
Grupo de Biotecnología-Productos Naturales, Escuela de Tecnología Química, Universidad Tecnológica de Pereira, \\ Pereira, A.A. 97, Colombia
}

The antioxidant activity of the crude n-hexane, dichloromethane, and methanol extracts from 25 species belonging to the Asteraceae, Euphorbiaceae, Rubiaceae, and Solanaceae families collected at natural reserves from the Eje Cafetero Ecorregión Colombia, were evaluated by using the spectrophotometric 1,1-diphenyl-2picrylhydrazyl (DPPH) free radical-scavenging method.

The strongest antioxidant activities were showed by the methanol and dichloromethane extracts from the Euphorbiaceae, Alchornea coelophylla $\left(I C_{50} 41.14 \mathrm{mg} / \mathrm{l}\right)$ and Acalypha platyphilla $\left(I C_{50} 111.99 \mathrm{mg} / \mathrm{l}\right)$, respectively. These two species had stronger DPPH radical scavenging activities than hydroquinone $\left({ }^{2} C_{50} 151.19\right.$ $\mathrm{mg} / \mathrm{l})$, the positive control. The potential use of Colombian flora for their antioxidant activities is discussed.

Key words: Asteraceae - 1,1-diphenyl-2-picrylhydrazyl (DPPH) - Euphorbiaceae - radical-scavenging - Rubiaceae - Solanaceae

In living organisms the reactive oxygen species (ROS) and reactive nitrogen species (RNS) are known to cause damage to lipids, proteins, enzymes, and nucleic acids leading to cell or tissue injury implicated in the processes of aging as well as in wide range of degenerative diseases including inflammation, cancer, atherosclerosis, diabetes, liver injury, Alzheimer, Parkinson, and coronary heart pathologies, among others (Duan et al. 2006). The ROS and the RNS include diverse reactive entities namely superoxide $\left(\mathrm{O}_{2}{ }^{-}\right)$, hydroxyl $\left(\mathrm{OH}^{*}\right)$, peroxyl $\left(\mathrm{ROO}^{\circ}\right)$, peroxinitrite $\left({ }^{\circ} \mathrm{ONOO}^{-}\right)$, and nitric oxide $\left(\mathrm{NO}^{\circ}\right)$ radicals, as well as non free radicals species as hydrogen peroxide $\left(\mathrm{H}_{2} \mathrm{O}_{2}\right)$, nitrous acid $\left(\mathrm{HNO}_{2}\right)$, and hypochlorous acid (HOCl) (Mavi et al. 2003).

On the other hand, the aerobic organisms developed antioxidant defense mechanisms that arrest the damage caused by ROS and RNS entities. The defence mechanisms can be enzymatic and non-enzymatic. In the enzymatic mechanisms are included, for instance, superoxide dismutase, catalase, glutathione reductase and peroxidase, and nitric oxide synthase enzymes, among others. On the contrary, in the non-enzymatic mechanisms are comprised antioxidants and trapping agents such as ascorbic acid, $\alpha$-tocopherol, $\beta$-carotene, glutathione, flavonoids, uric acid, cysteine, vitamin $\mathrm{K}$, serum albumin, bilirubin, and trace elements as zinc and selenium, among others (Chae et al. 2004). Both processes can contribute to prevent the damage caused by oxidative reactions.

Since the natural antioxidant mechanism in mammalians under some circumstances can be inefficient, a dietary intake of antioxidant compounds becomes an al-

Financial support: Universidad Tecnológica de Pereira, the Ministerio de Medio Ambiente, Vivienda y Desarrollo Territorial, Federación Nacional de Cafeteros de Colombia

+Corresponding autor: omosquer@utp.edu.co

Received 6 February 2007

Accepted 21 May 2007 ternative, once it has been suggested that there is an inverse relationship between dietary intake of antioxidants and the incidence of diseases caused by the deficiency on these substances (Antolovich et al. 2002). In recent years, synthetic antioxidants such as buthylated hydroxyanisole (BHA) and buthylated hydroxytoluene (BHT) are added to food preparations because they are good free radical scavengers, even though there are some experimental evidences that they induce DNA damage (Sasaki et al. 2002). Therefore, there is an increasing interest in searching antioxidants from natural origin to scavenge free radicals to prevent human body from oxidative stress produced by ROS and RNS species (Gonçalves et al. 2005).

According to Hostettmann and Terreaux (2000), the estimated number of higher plant species in the world is of 400,000 , the fact that plant secondary metabolites are characterized by an enormous chemical diversity and that currently one-fourth of all prescribed pharmaceuticals compounds in developed countries are directly or indirectly (semi-synthetic) derived from plants. Then, the above statement in conjunction with the great Colombian biodiversity can make possible to discover new important antioxidant agents from such plethora of plant resources.

As plants produce a huge amount of antioxidants they can represent a source of new compounds with antioxidant activities (Cuendet et al. 2000, Bassman 2004). From this point of view, the main goal of this research was to study the antioxidant activities through the 1,1diphenyl-2-picrylhydrazyl (DPPH) radical-scavenging method of the crude $n$-hexane, dichloromethane, and methanol extracts from 25 plant species belonging to four botanical families (Asteraceae, Euphorbiaceae, Rubiaceae, and Solanaceae) collected from natural reserves on the Eje Cafetero Ecorregión (ECE), Colombia.

The ECE is an area constituted by the departments of Caldas, Quindío, and Risaralda, which are located on the Central Andean Colombian mountain chain, with an extension of $13.873 \mathrm{~km}^{2}$. Most of the ECE area is constituted by mountains with high mountain valleys, high pluviosity, and great natural resources diversity. 


\section{MATERIALS AND METHODS}

Materials - The solvents chloroform, dichloromethane, ethanol, $n$-hexane, and methanol were analytical grade Mallinckrodt (Chemicals Phillipsburg, NJ, US); dimethyl sulfoxide, hydroquinone, and analytical TLC silica gel $60 \mathrm{~F}_{254}$ plates were purchased from Merck (Darmstadt, Germany); while DPPH as free radical form was from Aldrich Chemical (Milwaukee, WI, US). The absorbance measurements were recorded on a Genesys 5 Milton Roy (2100) UV-VIS spectrophotometer (Rochester, NY, US).

Plant materials and extract preparations - Plant materials were collected in natural reserves from the ECE, Colombia, in November 2003 and identified by Dr FJ Roldán; voucher specimens for each plant were deposited at Universidad de Antioquia Herbarium (Medellín, Colombia) and are summarized in Table I.

The different collected plant materials were dried, milled, and extracted by maceration successively with the solvents $n$-hexane, dichloromethane, and methanol. Each plant extract was concentrated at $45^{\circ} \mathrm{C}$ under reduced pressure to dryness. The extracts were kept at $-10^{\circ} \mathrm{C}$ until they were submitted to the antioxidant assay.
Measurement of the DPPH radical scavenging activity - The scavenging reaction between $\left(\mathrm{DPPH}^{\circ}\right)$ and an antioxidant (H-A) can be written as:

$$
\begin{array}{ll}
\left(\mathrm{DPPH}^{\circ}\right)+(\mathrm{H}-\mathrm{A}) \rightarrow & \text { DPPH-H }+\left(\mathrm{A}^{*}\right) \\
\text { Purple } & \text { Yellow }
\end{array}
$$

Antioxidants react with $\mathrm{DPPH}^{\circ}$, which is a stable free radical and is reduced to the DPPH-H and as consequence the absorbances decreased from the $\mathrm{DPPH}^{\circ}$ radical to the DPPH-H form. The degree of discoloration indicates the scavenging potential of the antioxidant compounds or extracts in terms of hydrogen donating ability (Benabadji et al. 2004).

DPPH radical scavenging activity from all plant extracts were measured by the method described by BrandWilliams et al. (1995) with some modification, since the methanol extracts were dissolved in a methanol-water mixture (1:1) while the $n$-hexane and dichloromethane extracts were dissolved in a mixture constituted by dimethyl sulfoxide-ethanol-water (15:5:2).

First, each plant extract was evaluated at $250 \mathrm{mg} / \mathrm{l}$ by mixing $0.75 \mathrm{ml}$ of each extract with $1.5 \mathrm{ml}$ of a freshly prepared DPPH solution $(20 \mathrm{mg} / \mathrm{l})$; then, each particu-

\section{TABLE I}

Plants collected at different localities in the Eje Cafetero Ecorregión, Colombia with their voucher number and the percentage of

\begin{tabular}{|c|c|c|c|c|}
\hline \multirow[b]{3}{*}{ Plant family } & \multirow[b]{3}{*}{ Plant specie (Voucher number) } & \multicolumn{3}{|c|}{ DPPH radical scavenging activity $(\%)$} \\
\hline & & \multicolumn{3}{|c|}{ Plant extract } \\
\hline & & $n$-Hexane & Dichloromethane & Methanol \\
\hline \multirow[t]{5}{*}{ Asteraceae } & Vernonia canescens (FJR3908) & $21.770 \pm 0.005$ & $46.900 \pm 0.003$ & $43.193 \pm 0.004$ \\
\hline & Clibadium funzike (FJR3909) & $11.340 \pm 0.004$ & $45.060 \pm 0.001$ & $46.714 \pm 0.005$ \\
\hline & Calea angosturana (FJR3915) & $26.984 \pm 0.003$ & $38.390 \pm 0.004$ & $50.940 \pm 0.002$ \\
\hline & Pentacalia americana (FJR3916) & $19.730 \pm 0.005$ & $33.333 \pm 0.003$ & $49.531 \pm 0.004$ \\
\hline & Mikania leiostachya (FJR3924) & $35.374 \pm 0.004$ & $37.471 \pm 0.002$ & $38.500 \pm 0.004$ \\
\hline \multirow[t]{9}{*}{ Euphorbiaceae } & Hyeronima antioquiensis (FJR3905) & $20.181 \pm 0.003$ & $45.750 \pm 0.002$ & $50.940 \pm 0.001$ \\
\hline & Alchornea coelophylla (FJR3906) & $37.415 \pm 0.003$ & $57.012 \pm 0.002$ & $56.103 \pm 0.001$ \\
\hline & Acalypha platyphilla (FJR3910) & $46.940 \pm 0.001$ & $60.000 \pm 0.003$ & $53.521 \pm 0.003$ \\
\hline & Mabea montana (FJR3912) & $39.683 \pm 0.004$ & $45.060 \pm 0.003$ & $50.470 \pm 0.002$ \\
\hline & Acalypha sp. (FJR3914) & $29.025 \pm 0.004$ & $38.851 \pm 0.001$ & $43.900 \pm 0.002$ \\
\hline & Acalypha diversifolia(FJR3917) & $36.735 \pm 0.004$ & $47.590 \pm 0.003$ & $45.540 \pm 0.003$ \\
\hline & Euphorbia sp. (FJR3918) & $39.230 \pm 0.004$ & $42.760 \pm 0.002$ & $41.784 \pm 0.004$ \\
\hline & Hyeronima macrocarpa (FJR3925) & $19.050 \pm 0.003$ & $52.643 \pm 0.003$ & $50.470 \pm 0.003$ \\
\hline & Tetrorchidium andinum (FJR3927) & $24.040 \pm 0.003$ & $28.970 \pm 0.004$ & $27.700 \pm 0.002$ \\
\hline \multirow[t]{6}{*}{ Rubiaceae } & Cinchona pubescens (FJR3902) & $10.884 \pm 0.006$ & $23.780 \pm 0.005$ & $36.385 \pm 0.004$ \\
\hline & Ladambergia macrocarpa (FJR3903) & $13.832 \pm 0.002$ & $54.023 \pm 0.002$ & $45.540 \pm 0.003$ \\
\hline & Palicourea acetosoides (FJR3904) & $19.955 \pm 0.003$ & $40.920 \pm 0.002$ & $39.671 \pm 0.004$ \\
\hline & Palicourea sp. (FJR3907) & $22.450 \pm 0.001$ & $41.610 \pm 0.002$ & $41.080 \pm 0.003$ \\
\hline & Psychotria sp. (FJR3911) & $6.580 \pm 0.009$ & $30.115 \pm 0.001$ & $27.700 \pm 0.002$ \\
\hline & Rubiaceae sp. (FJR3913) & $9.751 \pm 0.006$ & $47.126 \pm 0.001$ & $52.582 \pm 0.002$ \\
\hline \multirow[t]{5}{*}{ Solanaceae } & Solanum ovalifolium (FJR3920) & $27.440 \pm 0.005$ & $37.012 \pm 0.002$ & $40.610 \pm 0.001$ \\
\hline & Solanum deflexiflorum (FJR3921) & $25.850 \pm 0.000$ & $34.253 \pm 0.004$ & $42.960 \pm 0.001$ \\
\hline & Solanum ocharanthum (FJR3922) & $33.790 \pm 0.002$ & $39.081 \pm 0.005$ & $32.863 \pm 0.003$ \\
\hline & Solanum brevifolium (FJR3923) & $26.984 \pm 0.004$ & $32.183 \pm 0.004$ & $43.900 \pm 0.001$ \\
\hline & Solanum leucocarpum (FJR3926) & $31.293 \pm 0.002$ & $32.190 \pm 0.002$ & $30.050 \pm 0.002$ \\
\hline \multicolumn{2}{|c|}{ Positive control: Hydroquinone } & & $43.982 \pm 0.401$ & \\
\hline
\end{tabular}
1,1-diphenyl-2-picrylhydrazyl (DPPH) radical scavenging activity values for each plant extract evaluated at $250 \mathrm{mg} / \mathrm{l}$ 
lar mixture was shaken and left to stand for $30 \mathrm{~min}$ at room temperature in darkness. After that, each mixture was tested for the DPPH radical scavenging activity by reading the absorbance at $517 \mathrm{~nm}$ on an UV-VIS spectrophotometer. As blank a solution prepared by mixing $0.75 \mathrm{ml}$ of ultra pure water with $1.5 \mathrm{ml}$ of the DPPH solution $(20 \mathrm{mg} / \mathrm{l})$ was used and read at the same wavelength. In addition, to eliminate the absorbance of the crude extracts at this wavelength, blank samples were prepared with $0.75 \mathrm{ml}$ of each extract and $1.5 \mathrm{ml}$ of ultra pure water. The DPPH radical scavenging activity percentage was calculated by using the following formula:

$$
\begin{aligned}
& \text { DPPH radical scavenging activity }(\%)= \\
& \left.=\left[\mathrm{A}_{\text {Control }}-\mathrm{A}_{\text {Extract }}\right) / \mathrm{A}_{\text {Control }}\right] \times 100
\end{aligned}
$$

where $\mathrm{A}_{\text {Control }}$ is the absorbance of a DPPH solution without extract, $A_{\text {Extract }}$ is the absorbance of the tested extract, which is equal to the absorbance of the plant extract plus the DPPH $(20 \mathrm{mg} / \mathrm{l})$ minus the blank extract absorbance at the same concentration tested without the DPPH solution. As positive control hydroquinone at 250 $\mathrm{mg} / \mathrm{l}$ was used. All measurements were performed in triplicate. The results are presented as mean $\pm \mathrm{SD}$.

Secondly, the plant extracts with DPPH radical scavenging activity percentages equal or higher than $45 \%$, were tested to $500,250,125,62.5,31.25$, and $15.62 \mathrm{mg} / \mathrm{l}$ to obtain the inhibitory concentration $\left(\mathrm{IC}_{50}\right)$, through a linear regression analysis. $\mathrm{IC}_{50}$ value is the sample concentration required to scavenge $50 \%$ of the DPPH free radicals.

Phytochemical tests - For each plant extract a phytochemical screening was performed for testing the presence of secondary metabolites by TLC analyses. The solvent system for polar extracts was chloroform-ethyl acetate-methanol $(2: 2: 1)$ and for non-polar extracts was hexane-ethyl acetate $(8: 2)$. The following spray reagents were used in order to develop the spots: anisaldehydesulphuric acid (sterols), 1\% ferric chloride (tannins), $2 \%$ aluminium chloride in ethanol (flavonoids), $1 \%$ vanillin in sulphuric acid-ethanol (saponins), and Dragendorff reagent (alkaloids) (Wagner \& Bladt 1996).

\section{RESULTS}

Since DPPH assay has been largely used as a quick, reliable, and reproducible parameter to search the in vitro general antioxidant activity of pure compounds as well as plant extracts (Koleva et al. 2002, Gonçalves et al. 2005), the potential antioxidant activities of 75 plant extracts from ECE were evaluated by this method and the results are shown on Table $\mathrm{I}$. In addition, the $\mathrm{IC}_{50}$ values for those plant extracts that displayed a DPPH radical scavenger capacity equal or higher than $45 \%$ were obtained and are shown in Table II. Each $\mathrm{IC}_{50}$ value was achieved from a linear regression analysis showing good correlation coefficient $\left(\mathrm{r}^{2} \geq 0.9\right)$.

Phytochemical tests on the methanol and dichloromethane extracts of Euphorbiaceae plants evaluated in this work revealed the presence of triterpenes, steroids, lactones, tannins, and phenols (data not shown) and to these phytocompounds can be attributed the antioxidant activity of these plant extracts.

\section{DISCUSSION}

In general, scavenging activities equal or higher than $45 \%$ were exhibited by the crude plant extracts of Euphorbiaceae $(24 \%)$, followed by Asteraceae (16\%), and the Rubiaceae $(8 \%)$ families.

From the 75 plant extracts evaluated, nine gave $\mathrm{IC}_{50}$ values lower than $200 \mathrm{mg} / \mathrm{l}$ and, from these, eight belonged to Euphorbiaceae and one to Rubiaceae families. The strongest $\mathrm{IC}_{50}$ values were given by the methanol extract from A. coelophylla $(41.14 \mathrm{mg} / \mathrm{l})$ followed by the dichloromethane extract of A. platyphilla (111.99 $\mathrm{mg} / \mathrm{l}$ ), both plants belonging to the Euphorbiaceae family (Table II). Interestingly, the only plant species in this study that showed an important $\mathrm{IC}_{50}$ value with the three different extracts assessed was A. platyphilla.

The results on this work with the Euphorbiaceae family correlates with several results found on the scientific literature as are the cases of the methanol, chloroform, ethyl acetate, $n$-butanol, and aqueous fractions as well as pure compounds isolated from Euphorbia thymifolia L. (Euphorbiaceae), that displayed antioxidant activities as was evidenced by the cytochrome $\mathrm{C}$ reduction method (Lin et al. 2002). In addition, the crude extracts, fractions, and isolated compounds from Croton celtidifolius Baill (Euphorbiaceae) showed in vitro antioxidant properties through the superoxide scavenger capacity method by the nitro blue tetrazolium (NBT) reduction assay (Nardi et al. 2003). Furthermore, the Euphorbiaceae Phyllanthus amarus Schum \& Thonn has been used as a good in vitro and in vivo antioxidant agent because of its powerful scavenger properties of oxygen radicals (Kumar \& Kuttan 2005).

The results from the phytochemical screening are in consonance with previous works; for instance, the antioxidant activity of $C$. celtidifolius bark showed abundance of phenolic compounds such as catechin, gallocatechin, and proanthocyanidins as phytochemical constituents which are the responsible for the antioxidant properties of this specie (Nardi et al. 2003); from Phyllanthus niruri (Harish \& Shivanandappa 2006) as well as from $P$. amarus have been isolated a variety of tannins, several lignans, and flavonoids such as quercetin and catechin as responsible for the antioxidant activity of these two plants (Kumar \& Kuttan 2005). In general, it is well known that polyphenolic compounds are widely distributed in plant kingdom and they have shown to possess strong antioxidant properties (Badami et al. 2003, Javanmardi et al. 2003, Benabadji et al. 2004, Dar et al. 2005).

In conclusion, this study provides evidence that the species A. coelophylla and A. platyphilla (Euphorbiaceae) have antioxidant properties, as tested through the DPPH method. Therefore, these species may have great relevance in the prevention and therapies of diseases in which oxidants or free radicals are implicated. In addition, these plants can be good candidates for further phytochemical and chromatographic studies to isolate and fully characterize the compounds related to this in vitro biological activity.

\section{ACKNOWLEDGEMENTS}

To CARDER for granting the permissions to plant collection. 
TABLE II

Inhibitory concentration $\left(\mathrm{IC}_{50}\right.$ ) values for each plant extract with percentages of 1,1-diphenyl-2-picrylhydrazyl (DPPH) radical scavenging activity higher than $45 \%$

\begin{tabular}{|c|c|c|c|c|}
\hline \multirow[b]{3}{*}{ Plant family } & \multirow[b]{3}{*}{ Plant specie } & \multicolumn{3}{|c|}{$\mathrm{IC}_{50}(\mathrm{mg} / \mathrm{l})$} \\
\hline & & \multicolumn{3}{|c|}{ Plant extract } \\
\hline & & $n$-Hexane & Dichloromethane & Methanol \\
\hline \multirow[t]{4}{*}{ Asteraceae } & Vernonia canescens & NE & 282.65 & $\mathrm{NE}$ \\
\hline & Clibadium funzike & $\mathrm{NE}$ & 349.46 & 848.27 \\
\hline & Calea angosturana & NE & NE & 317.44 \\
\hline & Pentacalia americana & NE & NE & 245.20 \\
\hline \multirow[t]{6}{*}{ Euphorbiaceae } & Hyeronima antioquiensis & NE & 344.74 & 147.61 \\
\hline & Alchornea coelophylla & $\mathrm{NE}$ & 126.38 & 41.14 \\
\hline & Acalypha platyphilla & 269.45 & 111.99 & 189.17 \\
\hline & Mabea montana & $\mathrm{NE}$ & 495.82 & 185.18 \\
\hline & Acalypha diversifolia & $\mathrm{NE}$ & 190.82 & 941.80 \\
\hline & Hyeronima macrocarpa & $\mathrm{NE}$ & 168.47 & 339.48 \\
\hline \multirow[t]{2}{*}{ Rubiaceae } & Ladambergia macrocarpa & NE & 180.16 & 377.56 \\
\hline & Rubiaceae sp. & NE & 244.65 & 223.12 \\
\hline \multicolumn{2}{|c|}{ Positive control: Hydroquinone } & & 151.19 & \\
\hline
\end{tabular}

NE: no evaluated.

\section{REFERENCES}

Antolovich M, Prenzler P, Patsalides E 2002. Methods for testing antioxidant activity. Analyst 127: 183-198.

Badami S, Moorkoth S, Rai RS, Kannan E, Bhojraj S 2003. Antioxidant activity of Caesalpinia sappan hearwood. Biol Pharm Bull 26: 1534-1537.

Bassman JH 2004. Ecosystem consequences of enhanced solar ultraviolet radiation: secondary plant metabolites as mediators of multiple trophic interactions in terrestrial plant communities. Photochem Photobiol 79: 382-398.

Benabadji SH, Wen R, Zheng J-B, Dong X-C, Yuan S-G 2004. Anticarcinogenic and antioxidant activity of diindolylmethane derivatives. Acta Pharmacol Sin 25: 666-671.

Brand-Williams W, Cuvelier M, Berset C 1995. Use of a free radical method to evaluate antioxidant activity. Lebensm Wiss Technol 28: 25-30.

Chae S, Kim JS, Kang KA, Bu HD, Lee Y, Hyun JW, Kang SS 2004. Antioxidant activity of Jionoside D from Clerodendron trichotomun. Biol Pharm Bull 27: 1504-1508.

Cuendet M, Potterat O, Salvi A, Testa B, Hostettmann K 2000. A stilbene and dihydrochalcone with radical scavenging activities from Loiseleuria procombens. Phytochemistry 54: 871-874.

Dar A, Faizi S, Naqvi S, Roome T, Rehman SZ-U, Ali M, Firdous S, Moin ST 2005. Analgesic and antioxidant activity of mangiferin and its derivatives: the structure activity relationship. Biol Pharm Bull 28: 596-600.

Duan X-J, Zhang W-W, Li X-M, Wang B-G 2006. Evaluation of antioxidant property of extract and fractions obtained from a red alga, Polysiphonia urceolata. Food Chem 95: 37-43.

Gonçalves C, Dinis T, Batista MT 2005. Antioxidant properties of proanthocyanidins of Uncaria tomentosa bark decoction: a mechanism for anti-inflammatory activity. Phytochemistry 66: 89-98.
Harish R, Shivanandappa T 2006. Antioxidant activity and hepatoprotective potential of Phyllanthus niruri. Food Chem 95: 180-185.

Hostettmann K, Terreaux C 2000. Search for new lead compounds from higher plants. Chimia (Aarau) 54: 652-657.

Javanmardi J, Stushnoff C, Locke E, Vivanco JM 2003. Antioxidant activity and total phenolic content of Iranian Ocimum accessions. Food Chem 83: 547-550.

Koleva II, van Beek T, Linssen JPH, de Groot A, Evstatieva LN 2002. Screening of plant extracts for antioxidant activity: a comparative study on three testing methods. Phytochem Anal 13: 8-17.

Kumar KBH, Kuttan R 2005. Chemoprotective activity of an extract of Phyllanthus amarus against cyclophosphamide induced toxicity in mice. Phytomedicine 12: 494-500.

Lin CC, Cheng HY, Yang CM, Lin TC 2002. Antioxidant and antiviral activities of Euphorbia thymifolia L. J Biomed Sci 9: 656-664.

Mavi A, Terzi Z, Ozoen U, Yildirim A, Coskun M 2003. Antioxidant properties of some medicinal plants: Prangos ferulacea (Apiaceae), Sedum sempervivoides (Crassulaceae), Malva neglecta (Malvaceae), Cruciata taurica (Rubiaceae), Rosa pimpinellifolia (Rosaceae), Galium verum subsp. verum (Rubiaceae), Urtica dioica (Urticaceae). Biol Pharm Bull 27: 702-705.

Nardi GM, Felippi R, Dalbó S, Siqueira-Junior JM, Arruda DC, Delle Monanche F, Timbola AK, Pizzolatti MG, Ckless K, Ribeiro-do-Valle RM 2003. Anti-inflammatory and antioxidant effects of Croton celtidifolius bark. Phytomedicine 10: $176-184$.

Sasaki YF, Kawaguchi S, Kamaya A, Ohshita M, Kabasawa K, Iwama K, Taniguchi K, Tsuda S 2002. The comet assay with 8 mouse organs: Results with 39 currently used food additives. Mut Res-Gen Tox En 519: 103-109.

Wagner H, Bladt S 1996. Plant Drug Analysis, Springer, Berlin, $384 \mathrm{pp}$. 